\title{
USE OF DNA TECHNOLOGY IN FORENSIC DENTISTRY
}

\author{
Ricardo Henrique Alves da SILVA ${ }^{1}$, Arsenio SALES-PERES ${ }^{2}$, Rogério Nogueira de OLIVEIRA ${ }^{3}$, \\ Fernando Toledo de OLIVEIRA ${ }^{4}$, Sílvia Helena de Carvalho SALES-PERES ${ }^{2}$
}

\author{
1- DDS, MSc, PhD student, Dental School, University of São Paulo, São Paulo, SP, Brazil, Assistant Professor, Health Sciences Institute, \\ Paulista University (Unip), Bauru, SP, Brazil \\ 2- DDS, MSc, PhD, Assistant Professor, Bauru School of Dentistry, University of São Paulo (USP), Bauru, SP, Brazil \\ 3- DDS, MSc, PhD, Assistant Professor, Dental School, University of São Paulo (USP), São Paulo, SP, Brazil \\ 4- DDS, MSc, Assistant Professor, Paulista University (Unip), Bauru, SP, Brazil \\ Corresponding address: Ricardo Henrique Alves da Silva - Rua Minas Gerais, 12-67, Parque Paulistano, Bauru, SP, Brasil - \\ Phone: 5514 9115-3383 - e-mail: ricardohenrique@usp.br \\ Received: May 30, 2006 - Modification: September 11, 2006 - Accepted: December 11, 2006
}

\begin{abstract}
$T$

he established importance of Forensic Dentistry for human identification, mainly when there is little remaining material to perform such identification (e.g., in fires, explosions, decomposing bodies or skeletonized bodies), has led dentists working with forensic investigation to become more familiar with the new molecular biology techniques. The currently available DNA tests have high reliability and are accepted as legal proofs in courts. This article presents a literature review referring to the main studies on Forensic Dentistry that involve the use of DNA for human identification, and makes an overview of the evolution of this technology in the last years, highlighting the importance of molecular biology in forensic sciences.
\end{abstract}

Uniterms: Forensic dentistry; Human identification; DNA.

\section{INTRODUCTION}

The discipline of Forensic Dentistry has only been introduced to the curriculum of the Brazilian Dental Schools after issuing of Decree no. 19852, amended in $1931^{9}$. Since then, this specialty has continued to evolve, showing a remarkable scientific and professional maturity lately. Forensic Anthropology, which is one of the competences of Forensic Dentistry, is one of the best examples of this development, having passed through stages of simple observation to the recent sophisticated laboratory tests, including genetic examinations.

This way, Forensic Dentistry is the specialty with the goal of investigating psychological, physical, chemical and biological phenomena that can reach human beings (alive, dead or body fragments), comprehending aspects of human identification; criminal, civil, labor and administrative forensic investigation; forensic tanatology; legal documents; forensic traumatology; image (x-ray, tomography) examinations; saliva analysis; and other aspects involving a multidisciplinary team ${ }^{3}$.

Human identification is one of the major fields of study and research in forensic science because it deals with the human body and aims at establishing human identity. The revolution caused in 1953 by Watson and Crick ${ }^{43}$ (1953), who discovered the double-helix structure of DNA, which is responsible for the genetic inheritance of human beings, led to important changes in nearly all fields of science. This discovery was the basis for the development of techniques that allow characterizing each person's individuality based on the DNA sequence. Three decades later, Jeffreys, et al. ${ }^{15}$ (1985) created radioactive molecular probes that could recognize highly variable regions of DNA and thus determine the specific patterns of each individual, which were named DNA fingerprints. The currently performed DNA profile tests are totally reliable, being accepted as legal proofs in courts, such as for investigation of paternity and human identification ${ }^{26}$. Several biological materials may be employed for isolation of DNA and accomplishment of laboratory tests for human identification, including bone tissue, hair bulb, biopsy sample, saliva, blood and other body tissues. It is possible to obtain DNA from virtually all human body tissues, only with variations in the quantity and quality of the DNA extracted from each tissue.

The established importance of Forensic Dentistry for human identification, mainly when there is little remaining material to perform such identification (e.g. in fires, explosions, decomposing bodies or skeletonized bodies), has led dentists working with forensic investigation to become more familiar with the new molecular biology technologies. Therefore, this article presents a literature review referring to the recent Brazilian works and some international studies on Forensic Dentistry that used DNA analysis for human identification, and makes an overview 
of the evolution of this technology in the last years, highlighting the importance of molecular biology in cases of forensic investigation.

\section{LITERATURE REVIEW}

\section{Background}

Until the 1980's, the science of identification of criminal cases was based only on serological analyses of protein polymorphism, blood groups and some genetic markers. Forensic examination of biological samples started in the beginning of the twentieth century by application of the ABO blood group system in evidences related to crimes or human identification. The proofs of individual identification by use of blood group testing gained legal value in the German courts in 1920, being legally accepted in the United States only in 1935. In Brazil, these exams were given legal value with the first paternity investigation in 1948 ${ }^{7}$. These systems have been replaced in most centers and are rarely employed in present days ${ }^{23}$.

Another important phase in the development of forensic sciences directed at human identification started with the publication of a study by Jeffreys, et al. ${ }^{15}$ (1985), who investigated radioactive molecular probes that could recognize certain highly sensitive regions of DNA (minisatellites in human genome) that produced a type of DNA “fingerprint”. Molecular typing of the genetic material was officially employed for the first time in England by Jeffreys, et al. ${ }^{16}$ (1985), for resolution of an immigration problem. Year after year, these authors employed this technique to identify the rapist and murderer of two victims. Since then, Criminalistics and Forensic Medicine have further evolved and have applied DNA fingerprint molecular typing techniques as a powerful tool for resolution of thousands of crimes and for human identification ${ }^{23}$.

The first polymorphic locus in the human genome was discovered by Wyman and White ${ }^{44}$ (1980), using a DNA probe In this way, more than 15 different sizes could be observed in a small sample of subjects. These repeated sequences are spread throughout the human genome and present sufficient variety to be used in human identification tests. These hypervariable loci were constituted by tandem repeat of oligonucleotides sequences (from 2 to $80 \mathrm{bp}$ ). Depending on their size, these loci were nominated as VNTR (variable number of tandem repeat) or minisatellites, 9 to 80 $\mathrm{pb}$, and STR (short tandem repeats) or microsatellites, 2 to 5 $\mathrm{bp}^{24}$.

Initially, the forensic community used VNTR testing for body identification and paternity tests. However, as this method requires a large amount of material and has lowquality results, several cases could not be solved, especially when only little biological material samples were colleted in a scene crime investigation. The introduction of the polymerase chain reaction (PCR) technique, which makes possible the amplification of small DNA samples, widened the scopes in Forensic Genetics ${ }^{10}$. STR testing started being used for forensic casework, making a revolution on human identification and paternity tests.

In addition, newer DNA tools, including mitochondrial DNA and SNP (single nucleotide polymorphism replacements, insertions or deletions that occur at single positions in the human genome), might be used when STR typing fails to yield a result or when only a partial profile is obtained due to the size and conditions of the sample ${ }^{5}$. Poor quality DNA can be found, for example, in mass disaster, such as the World Trade Center attacks, airplane crashes, tsunamis and decomposing bodies.

DNA tests were accepted by the Brazilian legislation only after the 1990s and are still very questioned by some individuals. In addition, DNA testing involves a high cost due to the scarcity of public institutes prepared for routine accomplishment of DNA examinations. However, there are already evidence that the State recognizes the efficacy of the information provided by DNA tests and the consequent need to make them available to the general public ${ }^{22}$. For example, the Brazilian Federal District already follows the Law no. 1097/96, which assures the accomplishment of free DNA tests for persons with proven necessity ${ }^{7}$. In the São Paulo State, there is a project entitled "Caminho de Volta" (Way Back) that uses molecular biology technology in the search for missing children ${ }^{13}$. In addition to these initiatives, further laws on this topic are currently being developed, such as the Law Project no. 6610/02 proposed by the congressman Ricardo Izar, which foresees the creation of the State Bank of DNA, with the sole purpose of performing an initial identification record of newborns, and the Law Project no. 188/99 proposed by the congressman Alberto Fraga, which establishes the criminal genetic identification, among others ${ }^{28}$.

\section{DNA and Forensic Dentistry}

Forensic Dentistry has contributed remarkably to human identification processes. Protected by Law no. 5081/66, Brazilian dental professionals can carry out investigations involving biological materials derived from the human body in various conditions (quartered, dilacerated, carbonized, macerated, putrefied, in skeletonization and skeletonized), with the aim of establishing human identity ${ }^{24}$.

Fingerprints have been historically used for identification. However, in some situations, such as fire and skeletonization, they are easily destroyed. In addition, experts frequently need to use comparative elements of the victim produced prior to his/her death, such as the dental records, to carry on the identification. However, this documentation may be unavailable or incomplete. At present, with the application of biomolecular resources for human identification, it is possible to identify a person using small amounts of deteriorated biological material, conditions that are relatively frequent in forensic analyses ${ }^{8}$. This fact could be demonstrated after the South Asian tsunami disaster on December 26th 2004, when the most varied techniques were applied for identification of thousands of victims, such as forensic pathology, forensic dentistry, DNA profiling and fingerprinting. Even though, 99\% of the bodies were identified using dental records or fingerprints and only $1 \%$ 
of forensic identification was made by DNA profiling ${ }^{17,21}$.

The main exogenous factors that may limit the retrieval of information from body remnants and restrict the processes of human identification are the elements present or associated with fire, such as flames, heat and explosions ${ }^{19,20}$. In this sense, the teeth play an important role in identification and criminology, due to the high uniqueness of dental characteristics in addition to the relatively high degree of physical and chemical resistance of the dental structure ${ }^{21}$. Due to their capacity of enduring environmental changes, the teeth represent an excellent source of DNA because this biological material may provide the necessary relation for identification of an individual in case of failure of conventional methods for dental identification ${ }^{27}$.

\section{Genomic and Mitochondrial DNA in Forensic Dentistry}

The genomic DNA is found in the nucleus of each cell in the human body and represents a DNA source for most forensic applications. The teeth are an excellent source of genomic DNA because PCR analyses allow comparing the collected postmortem samples to known antemortem samples or parental DNA ${ }^{27,31}$.

Mitochondrial DNA is another type of material that can be used for body identification. Its main advantage is the high number of copies per cell (from hundreds to thousands of organelles). When the extracted DNA samples are too small or degraded, such as those obtained from skeletonized tissues, the likelihood of obtaining a DNA profile from mitochondrial DNA is higher than that with any marker found in genomic DNA ${ }^{39}$. Moreover, Silva and Passos ${ }^{33}$ (2002) stated that the analysis of mitochondrial DNA for forensic purposes is restricted to ancient tissues, such as bones, hair and teeth, in which the nuclear DNA cannot be analyzed. However, this examination is performed by direct sequencing of its nitrogenous bases, which is a very expensive technique because it employs a highly specialized technology. Furthermore, mitochondrial DNA is exclusively matrilineal and hence less informative. Thus, this analysis is not usual in all forensic laboratories directed at resolution of crimes and identification of persons ${ }^{42}$.

In a study conducted by Pötsch, et al. ${ }^{26}$ (1992), the total production of genomic DNA obtained from a dental sample ranged from $6 \mu \mathrm{g}$ to $50 \mu \mathrm{g}$ DNA. The results were obtained from DNA extracted from the dental pulp and did not show any difference when compared to the patterns obtained from DNA isolated from blood samples or available lung tissues.

In forensic samples, the study of DNA (genomic and mitochondrial) is usually performed by STR (short tandem repeats) analysis, which can be defined as hypervariable regions of DNA that present consecutive repetitions of fragments that have 2 to 7 base pairs (bp). The VNTR (variable number of tandem repeats) testing, which may present short repeated sequences of intermediate size (15 to 65 base pairs), is rarely used in forensic analyses due to the poor quality DNA provided with this method. The most valuable STRs for human identification are those that present greater polymorphism (greater number of alleles), smaller size (in base pairs), higher frequency of heterozygotes (higher than 90\%) and low frequency of mutations ${ }^{12}$.

\section{Possible Applications of DNA in Forensic Dentistry}

The environmental influence on the concentration, integrity and recovery of DNA extracted from dental pulps has been previously measured by Schwartz, et al..$^{32}$ (1991). The authors varied the $\mathrm{pH}$ (3.7 and 10.0$)$, temperature $\left(4^{\circ} \mathrm{C}\right.$, $25^{\circ} \mathrm{C}, 37^{\circ} \mathrm{C}$ and tooth incineration), humidity (20, 66 and $98 \%$ ), type of the soil in which the teeth were buried (sand, potting soil, garden soil, submersion in water and burying outdoors) and periods of inhumation (one week to six months). It was determined that the environmental conditions examined did not affect the ability to obtain high-molecular-weight human DNA from dental pulp.

Tsuchimochi, et al. ${ }^{40}$ (2002) tested the Chelex 100 chelating resin to extract DNA from the dental pulp for subsequent application on PCR analysis. For such purpose, the extracted teeth were incinerated for 2 minutes at temperatures of $100^{\circ} \mathrm{C}, 200^{\circ} \mathrm{C}, 300^{\circ} \mathrm{C}, 400^{\circ} \mathrm{C}$ and $500^{\circ} \mathrm{C}$. All samples incinerated at up to $300^{\circ} \mathrm{C}$ could be amplified and typed, whereas those incinerated at temperatures above $400^{\circ} \mathrm{C}$ did not produce any PCR product. The authors concluded that extraction of DNA from the dental pulp using this resin is appropriate for obtaining high-quality DNA samples for PCR amplification.

In order to evaluate the different dental tissues as DNA sources in forensic analyses, Malaver and Yunis ${ }^{18}$ conducted a study in 2003 in which 20 teeth were obtained from unidentified bodies buried in 1995 and exhumed in 2000, providing 45 DNA samples ( 5 from the pulp, 20 from dentin and 20 from cementum). The pulp produced the strongest PCR amplification signals, while dentin and cementum signals were very similar to each other. Hanaoka, et al. ${ }^{14}$ (1995) evaluated DNA extraction from 50 teeth (pulpal and hard tissues). The DNA obtained from the dental pulps ranged from 3 to $40 \mu \mathrm{g}$, and no correlation was found between the storage period and the amount of DNA. The authors investigated the efficiency of DNA extraction from hard dental tissues at different concentrations of a decalcifying solution. The DNA obtained from the dental pulp was of high molecular weight, which allowed analysis by multilocus probes or PCR. On the other hand, the material obtained from the hard dental tissues showed satisfactory analysis only by the PCR technique. Remualdo ${ }^{29}$ (2004) evaluated the PCR amplification of DNA retrieved from teeth subjected to heat $\left(200^{\circ} \mathrm{C}, 400^{\circ} \mathrm{C}, 500^{\circ} \mathrm{C}\right.$ and $\left.600^{\circ} \mathrm{C}\right)$ during 60 minutes, testing 3 different extraction methods (organic; ammonia acetate/isopropanol and silica). Using the organic method for genomic DNA extraction, $50 \%$ of samples subjected to burning were amplified, but only at lower temperatures $\left(200^{\circ} \mathrm{C}\right.$ and $\left.400^{\circ} \mathrm{C}\right)$. At higher temperatures $\left(500^{\circ} \mathrm{C}\right.$ and $\left.600^{\circ} \mathrm{C}\right)$, the isopropanol/ammonia acetate extraction method yielded better results, mainly for extraction of mitochondrial DNA.

Among the several cases described in the literature with DNA isolation from teeth, a very important report was 
published by Sweet and Sweet ${ }^{39}$ (1995). This paper presents a case of human remains identification in which a victim of murder was incinerated and had her body almost completely carbonized, reduced to approximately $25 \%$ of its original size, which then precluded DNA analysis by the usual methods. However, a preserved unerupted third molar enabled DNA extraction from the dental pulp (1.35 $\mu \mathrm{g})$, which was an excellent source of high molecular weight genomic DNA.

In addition to human identification, another subject of study of Forensic Dentistry related to molecular biology is the analysis of bite mark evidence. In cases of physical assault, such as sexual abuse, murders and child abuse, bite marks are frequently found on the skin ${ }^{34}$. The aggressor's saliva is usually deposited on the victim's skin during biting, kissing or suction. According to Sweet ${ }^{36}$ (2000), it is possible to identify the aggressor's blood group by the ABO system in $90 \%$ of cases, but this method is not very informative and would not be used if DNA amplification techniques, such as STR profiling, are available. From these cells, it is also possible to isolate DNA for identification of the aggressor.

Several studies are currently being conducted in order to optimize the methodology of DNA extraction from the saliva deposited on the skin to be used as evidence in forensic cases, such as the double-swab testing. According to Anzai, et al. ${ }^{2}$ (2005), this examination allows establishing DNA profile in 4 of 5 tested samples composed of $250 \mu \mathrm{L}$ of saliva deposited on the skin. In addition to gathering cells from the human body itself, it is also possible to retrieve cell samples from objects that had contact with the body, which are called artifacts ${ }^{25}$. DNA can be isolated in sufficient amount for human identification by examination of chewing gums, cigarettes, bite marks in foods, among others ${ }^{11,38}$.

\section{Careful Handling of Samples, DNA Extraction and PCR Amplification}

As observed, several protocols are used for DNA extraction and analysis, and there is no standard methodology. Therefore, researchers must carefully evaluate the conditions of the material to be examined, especially when dealing with forensic cases, in which there is a greater risk of sample contamination and influence of environmental factors, in addition to a small amount of material available in most situations ${ }^{7}$.

The PCR technique has been the usual choice for investigation of the frequencies of STRs ${ }^{1}$. This technique allows amplification of restricted regions of the human genome, associated with genomic hybridization. Recent developments of the technique of length amplification of polymorphic fragments have enhanced the potential of analysis of forensic samples ${ }^{7}$. Sweet ${ }^{35}$ (2001) stated that the PCR method enables differentiation of an individual from another, with a high level of reliability and with about $1 \mathrm{ng}$ (one one-billionth of a gram) of the target DNA.

According to Brown ${ }^{4}$ (1991), those who intend to work in forensic analysis laboratories adopting DNA examination as the methodology of choice, and especially those intending to use the PCR technique as a working tool should have attention and accuracy during sample handling as well as, follow strict policies to prevent contamination.

In practice, steps aiming at reliable results that might contribute to elucidate forensic cases are the adequacy of collection procedures, verification of the conditions of the collected material, choice of methodology for DNA extraction and analysis, and, finally the analysis of results ${ }^{7}$. It should be mentioned that DNA extraction is a process composed of 3 different stages: cell rupture or lysis (which allows use of several techniques for effective rupture of the cell membranes), protein denaturation and inactivation (by chelating agents and proteinases in order to inactive elements, such as proteins), and finally DNA extraction itself $^{41}$. The techniques of DNA extraction most often employed in Forensic Dentistry are the organic method (composed of phenol-chloroform and used for high molecular weight DNA, with a higher likelihood of errors, given the use of multiple tubes); Chelex 100 (the fastest with the lowest risk of contamination, yet very expensive); FTA Paper (composed of absorbent cellulose paper with chemical substances, which speed up its use); AND isopropyl alcohol (containing ammonium and isopropanol, which is less expensive and also an alternative to the organic method) ${ }^{6}$.

An important observation is when degraded sample in the ancient DNA are the only artefacts, being necessary using techniques to overcome the problems of contamination and degradation of DNA sample. Rudin and $\operatorname{Inman}^{30}$ (2001) have reported that the factors leading to the degradation of DNA include time, temperature, humidity (facilitating the growth of microorganisms), light (both sunlight and UV light) and exposure to various chemical substances. Combinations of these conditions are often found in the environment and tend to degrade the samples into smaller fragments. Therefore, once a sample has been collected, it must be dried (or remain dry), depending the type of biological material. It may also be stored frozen (if necessary), although for DNA this is less important than for the conventional protein and enzyme systems. The sample should not be subjected to fluctuations in either temperature or humidity ${ }^{30}$.

\section{CONCLUSION}

Violence and crimes against human life, such as bomb explosions, wars or plane crashes, as well as cases of carbonized bodies or in advanced stage of decomposition, among other circumstances, highlight the need to employ ever faster and more accurate methods during the process of identification of victims. In such cases, the findings of the several studies reviewed in this article demonstrate that the teeth represent an excellent source of DNA, which is protected by epithelial, connective, muscular and bone tissues in case of incineration. Additionally, the dental pulp cells are protected by enamel, dentin and cementum hard dental tissues. Therefore, dental professionals working on the field of Forensic Dentistry should incorporate these new 
technologies in their work, as several methods are available for DNA extraction from biological materials, yet standardization of the protocols adopted for such purpose has not been reached so far. For this reason, studies on molecular biology applied to human identification will probably further enhance DNA extraction with less material available and under increasingly adverse conditions.

\section{REFERENCES}

1- Anzai EK, Ozaki A, Nunes FD, Hirata M, Oliveira RN. Extração de DNA de saliva humana depositada sobre a pele e sua aplicabilidade aos processos de identificação individual. Odontol Soc. 2001;3(1/2):5-7.

2- Anzai EK, Hirata MH, Hirata RDC, Nunes FD, Melani RFA, Oliveira RN. DNA extraction from human saliva deposited on skin and its use in forensic identification procedures. Braz Oral Res. 2005;19(3):21622

3- Brasil. Conselho Federal de Odontologia. Resolução CFO 22/2001. Baixa normas sobre anúncio e exercício das especialidades odontológicas e sobre cursos de especialização, revogando as redações do capítulo VIII, título I; capítulos I, II e III, título III, das normas aprovadas pela resolução CFO-185/93, alterada pela resolução CFO198/95. Conselho Federal de Odontologia, Brasília, DF (2001 dez 27).

4- Brown TA. The essential techniques in molecular biology. In: Brown TA. Essential molecular biology. New York: Oxford University Press; 1991. p. 1-14.

5- Budowle B. SNP typing strategies. Forensic Sci Int. 2004;146 Suppl:S139-42.

6- Butler JM. Forensic DNA Typing: biology, technology and genetics of STR markers. San Diego: Academic Press; 2005.

7- Calabrez MCT, Saldanha PH. A pesquisa de DNA em odontologia forense. In: Silva M. Compêndio de odontologia legal. Rio de Janeiro: Editora Medsi; 1997. p. 167-221.

8- Corach D. Additional approaches to DNA typing skeletal remains: the search for "missing" persons killed during the last dictorship. Electrophoresis. 1997;18(9):1608-12.

9- Côrrea R. Comentários e anotações sobre a regulamentação da odontologia. In: Côrrea R. Regulamentação da odontologia. Curitiba: Instituto Paranaense de Estudos Superiores; 1976. p. 7-39.

10- Cotton EA, Allsop RF, Guest JL, Frazier RR, Koumi P, Callow IP, et al. Validation of the AMPFSTR SGM plus system for use in forensic casework. Forensic Sci Int. 2000;112:151-61.

11 - Frégeua CJ, Germain O, Fourney RM. Fingerprint enhancement revisited and the effects of blood enhancement chemicals on subsequent Profiler Plus fluorescent short tandem repeat DNA analysis of fresh and aged bloody Fingerprints. J Forensic Sci. 2000;45(2):35480 .

12- Galante-Filho H, Figini AL, Reis AB, Jobim LF, Silva M. Identificação humana. Porto Alegre: Editora Sagra Luzzatto; 1999.

13- Gattas GJF, Figaro-Garcia C, Fridman C, Battistella LR, Massad E, Neumann MM, et al. Projeto Caminho de Volta: busca de crianças desaparecidas no Estado de São Paulo. Rev Cult Extensão USP [periódico na internet]. 2005 [acesso em 2006 jan 10]. Disponível em: http://www.usp.br/prc/revista/pp2.html.
14- Hanaoka Y, Inoue M, Tsai TH, Minaguchi K. Fundamental and practical study for DNA analysis using tooth as a source of DNA. Nihon Hoigaku Zasshi. 1995;49(1):1-10.

15- Jeffreys AJ, Wilson V, Thein SL. Hypervariable 'minisatellite' regions in human DNA. Nature. 1985;314:67-73.

16- Jeffreys AJ, Brookfild JFY, Semeor FR. Positive identification of an immigration test-case using human DNA fingerprints. Nature. 1985;317:818-9.

17- Lau G, Tan WF, Tan PH. After the Indian Ocean Tsunami: Singapore's contribution to the international disaster victim identification effort in Thailand. Ann Acad Med Singapore. 2005;34(5):341-51.

18- Malaver PC, Yunis JJ. Different dental tissues as source of DNA for human identification in forensic cases. Forensic Sci. 2003;44(3):306-9.

19- Melani RFH. Identificação humana em vítimas de carbonização: análise odonto-legal através da microscopia eletrônica [tese]. Piracicaba (SP): Faculdade de Odontologia, Universidade de Campinas; 1999.

20-Miyajima F, Daruge E, Daruge E Júnior. A importância da odontologia na identificação humana: relato de um caso pericial. Arq Odontol. 2001;37(2):133-42.

21 - Morgan OW, Sribanditmongkol P, Perera C, Sulasmi Y, Van Alphen D, Sondorp E. Mass fatality management following the South Asian Tsunami Disaster: case studies in Thailand, Indonesia, and Sri Lanka. PLoS Med. 2006;3(6):809-15.

22- Moura RS Neto. Análise forense. Rev Panor Justiça. 1998;9:38.

23- Okamoto O, Yamamoto Y, Inagaki S, Yoshitome K, Ishikawa T, Imabayashi S, et al. Analysis of short tandem repeat (STR) polymorphisms by the powerplex 16 system and capillary electrophoresis: application to forensic practice. Acta Med Okayama. 2003;57(2):59-71.

24- Oliveira RN, Daruge E, Galvão LCC, Tumang AJ. Contribuição da odontologia legal para a identificação “post-mortem”. Rev Bras Odontol. 1998;55(2):117-22.

25- Pardini VC, Ferreira ACS, Gomes KB, Rodríguez SLB. Uso do DNA proveniente de polpa dentária para identificação humana: relato de caso e técnica. Rev Cons Reg Odontol Minas Gerais. 2001;7(1):335 .

26- Pötsch L, Meyer U, Rothschild S, Schneider PM, Rittner C. Application of DNA techniques for identification using human dental pulp as a source of DNA. Int J Legal Med. 1992;105:139-43.

27- Pretty IA, Sweet D. A look at forensic dentistry - part 1: the role of teeth in the determination of human identity. $\mathrm{Br}$ Dent $\mathrm{J}$. 2001;190(7):359-66.

28- Projeto Ghente. Documentos jurídicos [homepage na internet]. Rio de Janeiro; c2006 [acesso em 2006 fev 2]. Disponível em: http://www.ghente.org/doc_juridicos.

29- Remualdo VR. Avaliação de três métodos de extração de DNA de dentes humanos submetidos ao calor [dissertação]. São Paulo (SP): Faculdade de Odontologia, Universidade de São Paulo; 2004.

30- Rudin N, Inman K. An introduction to forensic DNA analysis. 2nd ed. Washington: CRC Press; 2001.

31- Santos CF, Sakai VT, Machado MAAM, Schippers DN, Greene AS. Reverse transcription and polymerase chain reaction: principles and applications in dentistry. J Appl Oral Sci. 2004;12(1):1-11. 
32- Schwartz TR, Schwartz EZ, Mieszerski L, McNally L, Kobilinsky L. Characterization of deoxyribonucleic acid (DNA) obtained from teeth subjected to various environmental conditions. J Forensic Sci. 1991;36(4):979-90

33- Silva LAF, Passos NS. DNA forense: coleta de amostras biológicas em locais de crime para estudo do DNA. Maceió: Ed UFAL; 2002.

34- Silva RHA, Musse JO, Melani RFH, Oliveira RN. Human bite mark identification and DNA technology in forensic dentistry. Braz J Oral Sci. 2006;5:1193-7.

35- Sweet D. Why a dentist for identification? Dent Clin North Am. 2001; 45(2):237-51.

36- Sweet D. Human bite mark evidence. In: Willems G. Forensic odontology: proceedings of the European IOFOS millennium meeting. Belgium: Leuven University Press; 2000. p. 75-9.

37- Sweet D, Dizzino JA. Personal identification through dental evidence - tooth fragments to DNA. J Calif Dent Assoc. $1996 ; 24(5): 35-42$.

38- Sweet D, Hildebrand D. Saliva from cheese bite yields DNA profile of burglar: a case report. Int J Legal Med. 1999;112:201-3.

39- Sweet D, Sweet CHW. DNA analysis of dental pulp to link incinerated remains of homicide victim to crime scene. J Forensic Sci. 1995;40:310-4

40- Tsuchimochi T, Iwasa M, Maeno Y, Koyama H, Inoue H, Isobe I, et al. Chelating resin-based extraction of DNA from dental pulp and sex determination from incinerated teeth with y-chromosomal alphoid repeat and short tandem repeats. Am J Forensic Med Pathol. 2002;23(3):268-71.

41- Vogel F, Motulsky AG, Motta PA. Genética humana: problemas e abordagens. Rio de Janeiro: Guanabara Koogan; 2000.

42- Walker MR, Rapley R. Guia de rotas na tecnologia do gene. São Paulo: Atheneu; 1999.

43- Watson JD, Crick FHC. A structure for deoxyribose nucleic acid. Nature. 1953;171:737-8.

44- Wyman AR, White R. A highly polymorphic locus in human DNA. Proc Natl Acad Sci USA. 1980;77(11):6754-8. 